Joyful Learning Journal

\title{
HUBUNGAN KEMANDIRIAN DAN KEAKTIFAN BELAJAR DENGAN HASIL BELAJAR PKN
}

\section{Yuris Setyawati $^{\bowtie}$ Arini Estiastuti}

Jurusan Pendidikan Guru Sekolah Dasar, Fakultas Ilmu Pendidikan, Universitas Negeri Semarang, Indonesia

\section{Info Artikel}

Sejarah Artikel:

Diterima Oktober

2017

Disetujui November

2017

Dipublikasikan

Desember 2017

\section{Keywords:}

learning activeness;

learning outcome;

self reliance

\begin{abstract}
Abstrak
Penelitian ini bertujuan untuk mengkaji hubungan kemandirian dan keaktifan belajar dengan hasil belajar PKn kelas V SDN Gugus Budi Utomo Mijen Kota Semarang. Jenis penelitian adalah penelitian korelasi. Populasi berjumlah 136 siswa dengan sampel 68 . Pengambilan sampel menggunakan teknik Proportional Random Sampling. Teknik pengumpulan data menggunakan angket, lembar pengamatan, dan tes. Hasil penelitian menunjukkan bahwa: (1) terdapat hubungan positif dan signifikan kemandirian belajar dengan hasil belajar PKn, termasuk kategori sedang yang ditunjukkan nilai $\mathrm{r}$ hitung $0,461)>(0,239) \mathrm{r}$ tabel dan nilai signifikansi $0,000<0,05$, (2) terdapat hubungan positif dan signifikan keaktifan belajar dengan hasil belajar PKn, termasuk kategori tinggi yang ditunjukkan nilai $r$ hitung 0,707$)>(0,239) r$ tabel dan nilai signifikansi $0,000<0,05$, (3) terdapat hubungan positif dan signifikan antara kemandirian dan keaktifan belajar dengan hasil belajar PKn, termasuk kategori tinggi yang ditunjukkan nilai $r$ hitung 0,743$)>(0,239) r$ tabel dan Fhitung $(40,144)>(3,138) F_{\text {tabel. }}$ Dengan demikian dapat disimpulkan bahwa terdapat hubungan positif dan signifikan antara kemandirian dan keaktifan belajar dengan hasil belajar PKn.
\end{abstract}

\begin{abstract}
This study aimed to examine the relation between self-reliance and learning activeness with civic education learning outcome of $5^{\text {th }}$ grade of SDN Gugus Budi Utomo Mijen Kota Semarang. The type of this research was correlation research. Population was 136 students, with 68 students as sample. Sample was taken by using Proportional Random Sampling technique. Data collection technique used questionnaire, observation sheet, and test. The result showed that: (1) there was a positive and significant relation of selfreliance with civic education indicated by $r$-value $(0.461)>r$ table $(0.239)$ and the significance value $0.000<0.05$, (2) there was a positive and significant relation of learning activeness with civic education learning outcome, indicated by $r$-value $(0.707)>r$ table (0.239) and the significance value $0.000<0.05$, (3) there was a positive and significant relation between self-reliance and learning activeness with civic education learning outcome indicated by $r$ value $(0.743)>r$ table $(0.239)$ and $F$ value $(40.144)>(3.138) \mathrm{F}$ table. The conclusion is there was a positive and significant relation between self-reliance and learning activeness with civic education learning outcome.
\end{abstract}

(C) 2017 Universitas Negeri Semarang

\footnotetext{
$\square$ Alamat korespondensi:

Desa Weton RT 01 RW 02 Kabupaten Rembang

E-mail: yurissetyawati@gmail.com
}

ISSN 2252-6366




\section{PENDAHULUAN}

Berdasarkan Permendiknas No. 22 Tahun 2006 tentang Standar Isi untuk Satuan pendidikan Dasar dan Menengah, Pendidikan Kewarganegaraan (PKn) merupakan salah satu mata pelajaran yang harus dipelajari di sekolah dasar. Pendidikan Kewarganegaraan bertujuan agar peserta didik dapat menjadi warga negara yang berkarakter. Karakter peserta didik dapat dibentuk di sekolah ketika proses pembelajaran seperti karakter yang mandiri dan aktif. Sikap kemandirian dan keaktifan belajar dapat mempengaruhi proses belajar peserta didik.

Fenomena peserta didik yang kurang mandiri sering terlihat dalam proses belajar. Hal ini dapat menimbulkan gangguan mental setelah memasuki pendidikan lanjutan, kebiasaan belajar yang kurang baik (seperti tidak betah belajar lama atau belajar hanya menjelang ujian, membolos, menyontek dan mencari bocoran soal-soal ujian). Proses belajar tidak hanya membutuhkan kemandirian saja tetapi juga memerlukan keterlibatan siswa secara aktif. Hamdani (2011:108) menjelaskan bahwa aktif mental lebih diinginkan daripada aktif fisik. Sering bertanya, mempertanyakan gagasan orang lain, dan mengungkapkan gagasan merupakan tanda-tanda aktif mental.

Berdasarkan hasil observasi data awal yaitu data dokumen dan wawancara terhadap guru kelas V di SDN Gugus Budi Utomo Kecamatan Mijen Kota Semarang, diperoleh data nilai hasil belajar ulangan akhir semester 1 pada ranah kognitif. Data nilai hasil belajar PKn pada siswa kelas $\mathrm{V}$ menunjukkan bahwa rata-rata kelas tiap sekolah sudah memenuhi KKM, namun belum semua siswa mendapat nilai mencapai KKM..

Berdasarkan hasil wawancara dengan guru kelas $\mathrm{V}$ juga diperoleh beberapa permasalahan lainnya yaitu guru sering menggunakan model konvensional, pemanfaatan media pembelajaran yang masih terbatas, kemandirian dan keaktifan siswa juga masih kurang maksimal. Hal ini terlihat dengan masih ada siswa yang mencontoh pekerjaaan teman, sebagian besar siswa masih memiliki kebiasaan belajar saat akan diadakan ulangan saja, mengandalkan temannya ketika mengerjakan tugas kelompok, sedikit siswa yang berani bertanya kepada guru, siswa masih malu dan ragu-ragu mengutarakan pendapat, siswa hanya diam dan mendengarkan saja.

Penelitian lain yang mendukung penelitian ini yaitu penelitian yang dilakukan oleh Syamsu Rijal (2015) dengan judul "Hubungan antara Sikap, Kemandirian Belajar, dan Gaya Belajar dengan Hasil Belajar Kognitif Siswa". Hasil penelitian menunjukkan bahwa terdapat hubungan yang positif dan signifikan antara kemandirian belajar siswa dengan hasil belajar kognitif Biologi siswa SMA Negeri 1 Ajangale Kabupaten Bone., dengan nilai korelasi sebesar 0,579 Nilai signifikansi sebesar 0,00. Nilai korelasi tersebut tergolong pada kategori cukup kuat. Nilai R2 sebesar 0,335 sehingga diperoleh koefisien determinasi (KP) sebesar 0,335 x 100\% $=33,5 \%$. Hal ini menunjukkan bahwa konstribusi kemandirian belajar terhadap hasil belajar kognitif biologi sebesar 33,5\%.

Penelitian serupa juga dilakukan HsiangI Chen (2015) dengan judul "Learner Autonomy and the Use of Language Learning Strategies in a Taiwanese junior High School". Hasil penelitiannya menunjukkan bahwa berdasarkan tabel analisis korelasi Pearson: Hubungan antara enam strategi pembelajaran dan tiga tingkat kemandirian belajar Bahasa Inggris menunjukkan bahwa ada korelasi positif antara kemandirian belajar Bahasa dan enam kategori strategi belajar bahasa. Tingkat kemandirian belajar siswa SMP dalam mempelajari Bahasa Inggris diukur dalam tiga dimensi yaitu tanggung jawab, kemampuan, dan aktivitas. Hasil penelitian menunjukkan 
bahwa mereka yang memiliki tingkat kemandirian yang tinggi dalam kemampuan dan aktivitas cenderung menerapkan strategi pembelajaran bahasa lebih sering. Korelasi yang signifikan tertinggi $(\mathrm{r}=0,74, \mathrm{p}<0,001)$ antara bagian aktivitas kemandirian dan strategi kognitif, yang menujukkan bahwa peserta didik yang lebih mandiri untuk kegiatan belajar Bahasa Inggris sangat mungkin untuk sering menggunakan strategi kognitif.

Penelitian yang dilakukan oleh Rostina Sundayana tahun 2016 dengan judul Kaitan antara Gaya Belajar, Kemandirian Belajar, dan Kemampuan Pemecahan Masalah Siswa SMP dalam Pelajaran Matematika. Hasil penelitiannya menunjukkan bahwa berdasarkan hasil uji Anova dua jalur menunjukkan bahwa kaitan antara kemampuan pemecahan masalah dengan kemandirian belajar siswa, diketahui bahwa terdapat perbedaan tingkat kemampuan pemecahan masalah matematis ditinjau dari tingkat kemandirian belajarnya, ditunjukkan dengan nilai Fhitung $=22,775$ dan Sig $=0,000$ yang lebih kecil dari $\alpha=0,05$, selanjutnya tidak terdapat pengaruh interaksi antara gaya belajar dengan kemandirian belajar terhadap kemampuan pemecahan masalah matematis siswa, ditunjukkan dengan nilai Fhitung $=0,761$ dan Sig $=0,560$ yang lebih besar dari $\alpha=0,05$.

Penelitian yang dilakukan oleh Sitti Fitriana, dkk. tahun 2015 dengan judul Pengaruh Efikasi Diri, Aktivitas, Kemandirian Belajar, dan Kemampuan Berpikir Logis Terhadap Hasil Belajar Matematika Pada Siswa Kelas VIII SMP. Hasil penelitiannya menunjukkan bahwa berdasarkan hasil analisis data penelitian efikasi diri berpengaruh signifikan secara langsung terhadap kemandirian belajar dengan tingkat kepercayaan 89\%, efikasi diri berpengaruh tidak signifikan secara tidak langsung terhadap hasil belajar melalui kemandirian belajar dengan tingkat kepercayaan
50\%, aktivitas belajar berpengaruh signifikan secara langsung terhadap kemandirian belajar dengan tingkat kepercayaan 99\%, aktivitas belajar berpengaruh tidak signifikan secara tidak langsung terhadap hasil belajar melalui kemandirian belajar dengan tingkat kepercayaan $50 \%$, kemandirian belajar berpengaruh tidak signifikan secara langsung terhadap hasil belajar dengan tingkat kepercayaan 22\%.

Penelitian yang dilakukan oleh Ramlah, dkk. tahun 2014 dengan judul Pengaruh Gaya Belajar dan Keaktifan Siswa Terhadap Prestasi Belajar Matematika SMP Negeri di Kecamatan Klari Kabupaten Karawang. Hasil penelitiannya menunjukkan bahwa terdapat pengaruh yang signifikan keaktifan terhadap prestasi belajar matematika, hal ini dapat dilihat dari nilai $\mathrm{F}$ hitung $=13,418>\mathrm{F}$ tabel $=3,08$, dengan sig= $0,00<\alpha=0,05$. Tidak terdapat pengaruh interaksi metode pembel;ajaran kooperatif dan gaya belajar terhadap prestasi belajar Matematika.

Penelitian yang dilakukan oleh Stephanie Mckendry dan Vic Boyd tahun 2012 dengan judul Defining the "Independent Learner"in UK Higher Education: Staff and Students' Understanding of the Concept. Hasil penelitiannya menunjukkan bahwa berdasarkan tabel tentang tanggapan siswa terhadap kuisioner yang dibagi menjadi beberapa kategori, analisis total untuk setiap pertanyaan bahwa mayoritas responden $(72,1 \%)$ memiliki kemampuan memahami ungkapan pembelajar mandiri. Pada tabel tentang tanggapan siswa terhadap pengertian belajar mandiri menunjukkan bahwa tanggung jawab dan otonomi siswa tampaknya paling signifikan. Minoritas siswa $(25,3 \%)$ merasa belajar mandiri mampu menyelesaikan penilaian tanpa dukungan apapun. Mayoritas siswa $(70,8 \%)$ melihat belajar mandiri sebagai suatu proses. Namun berbeda dengan kelompok lain, hampir setengah responden (44,7\%), 
percaya bahwa seorang siswa sudah harus menjadi pelajar yang mandiri. Temuan penelitian ini menunjukkan bahwa konsep tetap digunakan untuk memvalidasi penelitian lain, sementara gagasan tentang belajar mandiri jelas berguna untuk menyoroti sifat belajar siswa.

Penelitian yang dilakukan oleh Everlyn Oluoch tahun 2014 dengan judul Method of Increasing Speaking Activities in the Classroom (Maximising Student Input and Involvement) menunjukkan bahwa partisipasi siswa dalam pem-belajaran akan menjadikan siswa lebih komunikatif. Belajar aktif sebagian besar terlihat pada kegiatan diskusi. Diskusi dalam kelompok kecil/besar akan menciptakan interaksi antar siswa dan guru. Menjawab pertanyaan pemahaman bersama kelompok mendorong komunikasi siswa dan siswa didorong untuk mem-bandingkan jawaban dan mendiskusikan. Kegiatan ini membuat siswa menjadi lebih interaktif dan komunikatif.

Rumusan masalah pada penelitian ini adalah (1) Apakah terdapat hubungan kemandirian belajar dengan hasil belajar PKn siswa kelas V SDN Gugus Budi Utomo Kecamatan Mijen Kota Semarang? (2) Apakah terdapat hubungan keaktifan belajar dengan hasil belajar PKn siswa kelas V SDN Gugus Budi Utomo Kecamatan Mijen Kota Semarang? (3) Apakah terdapat hubungan kemandirian dengan Keaktifan belajar secara bersama-sama dengan hasil belajar PKn siswa kelas V SDN Gugus Budi Utomo Kecamatan Mijen Kota Semarang? (4) Seberapa besar hubungan kemandirian dengan Keaktifan belajar secara bersama-sama dengan hasil belajar PKn siswa kelas V SDN Gugus Budi Utomo Kecamatan Mijen Kota Semarang?

\section{METODE PENELITIAN}

Jenis penelitian ini adalah penelitian korelasi. Penelitian korelasi merupakan penelitian yang dimaksudkan untuk mengetahui ada tidaknya hubungan antara dua atau beberapa variabel. Desain penelitian yang digunakan adalah paradigma ganda dengan dua variabel independen. Variabel independennya yaitu kemandirian belajar dan keaktifan belajar, variabel dependennya yaitu hasil belajar PKn. Populasi penelitian ini adalah 136 siswa dengan sampel 68 siswa. Pengambilan sampel dilakukan dengan teknik Proportionate Random Sampling. Metode pengambilan data penelitian yaitu angket, lembar observasi dan tes. .Angket digunakan untuk mendapatkan data kemandirian belajar siswa. Lembar observasi untuk mendapatkan data keaktifan belajar, penilaian sikap, dan penilaian psikomotor. Tes digunakan untuk mendapatkan data hasil belajar PKn Materi Kebebasan Berorganisasi.

Analisis uji coba instrumen meliputi validitas, reliabilitas, taraf kesukaran dan daya beda. Analisis data menggunakan statistik deskriptif, uji prasyarat, dan uji hipotesis. Analisis statistik deskriptif digunakan untuk menghitung kemandirian belajar, keaktifan belajar dan hasil belajar. Uji prasyarat menggunakan uji normalitas dan uji linieritas. Uji hipotesis menggunakan korelasi sederhana, korelasi ganda, uji $\mathrm{T}$, uji $\mathrm{F}$ dan koefisien determinasi.

Analisis korelasi sederhana dengan rumus product moment digunakan untuk mengkaji apakah terdapat hubungan antara kemandirian belajar dengan hasil belajar Pkn, serta hubungan keaktifan belajar dengan hasil belajar PKn. Analisis korelasi ganda, uji T, uji F digunakan untuk mengkaji apakah terdapat hubungan kemandirian dan keaktifan belajar secara bersama-sama dengan hasil belajar PKn. Koefisien determinasi digunakan untuk mengetahui seberapa besar hubungan kemandirian dan keaktifan belajar secara bersama-sama dengan hasil belajar PKn. 


\section{HASIL DAN PEMBAHASAN}

Hasil penelitian tentang hubungan kemandirian dan keaktifan belajar dengan hasil belajar PKn meliputi:

\section{Data Kemandirian Belajar}

Data kemandirian belajar siswa diperoleh dari angket kemandirian belajar. Data penelitian yang telah dianalisis menghasilkan skor terendah 86 dan skor tertinggi 132, skor rata-rata (X) sebesar 116,19 dan standar deviasi (SD) sebesar 9,120. Hasil uji statisik deskriptif dapat dilihat dalam tabel berikut.

Tabel 1 Kategori Kemandirian Belajar

\begin{tabular}{cccc}
\hline Skor & Jumlah & Presentase & Kategori \\
\hline 130 ke atas & 3 & $4,41 \%$ & $\begin{array}{c}\text { Sangat } \\
\text { tinggi }\end{array}$ \\
$121-129$ & 21 & $30,88 \%$ & Tinggi \\
$112-120$ & 29 & $42,65 \%$ & Cukup \\
$103-111$ & 10 & $14,71 \%$ & Rendah \\
102 ke bawah & 5 & $7,35 \%$ & $\begin{array}{c}\text { Sangat } \\
\text { rendah }\end{array}$ \\
\hline
\end{tabular}

Berdasarkan tabel 1 dapat disimpulkan bahwa tingkat kemandirian siswa kelas V SDN Gugus Budi Utomo Kota Semarang sebagian besar berada pada kategori cukup.

\section{Data Keaktifan Belajar}

Data keaktifan belajar siswa diperoleh dari lembar observasi. Data keaktifan belajar siswa memiliki rerata sebesar 7,79, median 8 dan standar deviasi 1,997. Skor tertinggi yaitu 11 dan skor terendah yaitu 4. Hasil uji statisik deskriptif keaktifan bertanya siswa dapat dilihat dalam tabel berikut.

Tabel 2 Kategori Keaktifan Belajar

\begin{tabular}{cccc}
\hline Skor & Jumlah & Presentase & Kategori \\
\hline 11 ke atas & 7 & $10,29 \%$ & $\begin{array}{c}\text { Sangat } \\
\text { tinggi }\end{array}$
\end{tabular}

\begin{tabular}{cccc}
$9-10$ & 18 & $26,47 \%$ & Tinggi \\
$7-8$ & 25 & $36,77 \%$ & Cukup \\
$5-6$ & 14 & $20,59 \%$ & Rendah \\
4 ke bawah & 4 & $5,88 \%$ & $\begin{array}{c}\text { Sangat } \\
\text { rendah }\end{array}$ \\
\hline
\end{tabular}

Berdasarkan tabel 2 dapat disimpulkan bahwa tingkat keaktifan belajar siswa kelas V SDN Gugus Budi Utomo Kota Semarang sebagian besar berada pada kategori cukup.

Tabel 3 Kategori Hasil Belajar PKn

IntervalFrekuensi Presentase Kategori nilai

\begin{tabular}{cccc}
\hline $80-100$ & 15 & $22,06 \%$ & Baik sekali \\
$66-79$ & 24 & $35,29 \%$ & Baik \\
$56-65$ & 14 & $20,59 \%$ & Cukup \\
$40-55$ & 13 & $19,12 \%$ & Kurang \\
$30-39$ & 2 & $2,94 \%$ & Gagal
\end{tabular}

Berdasarkan tabel 3 dapat disimpulkan bahwa sebagian besar hasil belajar PKn siswa kelas V SDN Gugus Budi Utomo Kota Semarang berada pada kategori baik.

\section{Uji Normalitas}

Uji normalitas dalam penelitian ini dilakukan pada variabel hasil belajar PKn. Uji normalitas digunakan peneliti untuk menentukan apakah data berdistribusi normal atau tidak.

Berdasarkan hasil uji normalitas didapatkan nilai pada variabel kemandirian sebesar 0,074, keaktifan belajar sebesar 0,084 dan hasil belajar sebanyak 0,2. Masing-masing variabel memiliki nilai signifikasi lebih besar dari 0,05 , dengan demikian kedua variabel dinyatakan berdistribusi normal.

\section{Uji Hipotesis}

1. Hubungan Kemandirian Belajar dengan Hasil Belajar PKn

Hasil analisis data penelitian yang telah dilakukan menunjukkan bahwa variabel kemandirian belajar mempunyai nilai 


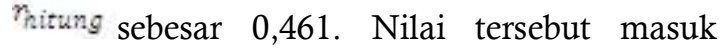
dalam kategori sedang. Nilai $\eta_{\text {hitung }}(0,461)>$ $(0,239){ }^{r_{\text {tabel }}}$ dan nilai signifikansi $0,000<0,05$. Tingkat signifikan ditunjukkan dengan nilai thitung $(2,767)>(1,669)$ tabel. Hal ini menunjukkan bahwa terdapat hubungan positif dan signifikan antara kemandirian belajar dengan hasil belajar PKn.

Hasil penelitian ini diperkuat dengan penelitian yang dilakukan oleh Asep Saefullah, dkk. tahun 2013 dengan judul Hubungan Antara Sikap Kemandirian Belajar Dan Prestasi Belajar Siswa Kelas X Pada Pembelajaran Fisika

\section{Data Hasil Belajar PKn}

Hasil belajar PKn diperoleh melalui rata-rata nilai kognitif, afektif dan psikomotor. Data hasil belajar menunjukkan bahwa nilai yang paling rendah adalah 37 dan nilai tertinggi 91 Standar deviasi sebesar 13,619 dan memiliki rata-rata sebesar 67,01. Berbasis Portofolio. Penelitian tersebut menunjukkan bahwa nilai rhitung $=0,640$ $>$ rtabel $=0,355$. Sehingga, dapat disimpulkan bahwa terdapat hubungan yang positif (searah) antara sikap kemandirian belajar dan prestasi belajar. Hasil uji signifikasi menunjukan bahwa nilai $x^{2}$ hitung $(12,70)>x^{2}$ tabel $(3,84)$, hal ini berarti terdapat hubungan positif yang cukup berarti antara sikap kemandirian belajar yang dimiliki siswa dengan prestasi belajar yang diperolehnya.

\section{Hubungan Keaktifan Belajar dengan} Hasil Belajar PKn

Hasil analisis data penelitian yang telah dilakukan menunjukkan bahwa variabel keaktifan belajar mempunyai nilai rhitung sebesar 0,707 . Nilai tersebut masuk dalam kategori tinggi. Nilai rhitung $(0,707)>(0,239)$ rtabel dan nilai signifikansi $0,000>0,05$. Tingkat signifikan ditunjukkan dengan nilai thitung $(7,026)>(1,669)$ tabel. Hal ini menunjukkan bahwa terdapat hubungan positif dan signifikan antara keaktifan belajar dengan hasil belajar PKn.

Hasil penelitian ini diperkuat dengan penelitian yang dilakukan oleh Pembeu Olfin tahun 2014 dengan judul Hubungan Keaktifan di Kelas dengan Hasil Belajar Siswa pada Kelas V Di SDN 25 Palu. Berdasarkan hasil pengamatan diperoleh data bahwa pengamatan aktivitas siswa, yang berada pada kategori sangat baik sebanyak 6 siswa dan yang berada pada kategori baik sebanyak 15 siswa. Berdasarkan data hasil nilai rapor siswa masih terdapat 4 orang siswa yang memperoleh prestasi belajar yang belum mencapai ketuntasan, dengan peroleh nilai rata-rata hasil belajarnya, yaitu 55,57, bahwa tingkat keaktifan siswa dalam kegiatan pembelajaran memiliki hubungan erat dengan pencapaian prestasi belajar siswa. Hal ini terlihat pada presentase keaktifan siswa yang tinggi, memilki hubungan dengan prestasi belajar yang tinggi. Apabila siswa berada pada kategori cukup dan kurang, maka akan terlihat prestasi belajar yang rendah pula.

\section{Hubungan Kemandirian dan Keaktifan Belajar dengan Hasil Belajar PKn \\ Hasil analisis data menunjukkan bahwa} kemandirian belajar dan keaktifan belajar secara bersama-sama terdapat hubungan yang positif dan signifikan dengan hasil belajar PKn siswa kelas V SDN Gugus Budi Utomo Kota Semarang. Hal ini terlihat dari nilai 位ing $(0,743)>(0,239) r_{\text {tabel }}$ dan nilai Sig.F Change $0,000<0,05$. Tingkat signifikan ditunjukkan dengan nilai $F_{\text {hitung }}(40,144)>$ $(3,138)$ F tabel. $_{\text {. Nilai }}$ mitung $(0,743)$ masuk dalam kategori kuat. Besarnya hubungan antara kemandirian belajar dan keaktifan belajar secara bersama-sama dengan hasil belajar PKn dapat diketahui dari hasil perhitungan $R$ Square = $0,553=55,3 \%$. Hasil penelitian ini diperkuat 
dengan penelitian yang dilakukan oleh Dyahayu Yustianingrum dkk tahun 2015 dengan judul Hubungan Keaktifan dan Kemandirian Siswa terhadap Prestasi Belajar Matematika Siswa SMP Kelas VII. Hasil penelitian menunjukkan bahwa adanya hubungan yang positif dan signifikan antara keaktifan dan kemandirian siswa secara bersamaan terhadap prestasi belajar matematika. Hasil analisis korelasi antara keaktifan dan kemandirian secara bersa maan terhadap prestasi belajar matematika $W=$ 0,468. Untuk menguji signifikansi harga koefisiensi

$x^{2}$ (Chi Square)

korelasi dilakuka uji dan diperoleh harga hitung $=164,268$ sedangkan harga $x^{2}$ tabel $=77,9$ karena $x^{2}$ hitung $>x^{2}$ tabel maka $H_{0}$ ditolak. Jadi, terdapat hubungan yang positif dan signifikan antara keaktifan dan kemandirian siswa terhadap prestasi belajar matematika secara bersama-sama.

\section{SIMPULAN}

Berdasarkan hasil penelitian dan pembahasan, dapat disimpulkan bahwa hasil uji hipotesis menunjukkan bahwa terdapat hubungan yang positif dan signifikan kemandirian belajar dengan hasil belajar PKn, terdapat hubungan yang positif dan signifikan keaktifan belajar dengan hasil belajar PKn, serta terdapat hubungan yang positif dan signifikan kemandirian dan keaktifan belajar secara bersama-sama dengan hasil belajar PKn.

\section{UCAPAN TERIMAKASIH}

Peneliti mengucapkan terimakasih kepada kedua orang tua yang telah memberikan dukungan serta doa; kepada Pembimbing Utama, Dra. Arini Estiastuti, M.Pd., Pembimbing Pendamping, Dr. Drs. Ali Sunarso,
M.Pd. yang telah membimbing. Serta Kepala Sekolah yang telah memberikan izin kepada peneliti untuk melakukan penelitian di SDN Gugus Budi Utomo Kecamatan Mijen Kota Semarang.

\section{DAFTAR PUSTAKA}

Arikunto, Suharsimi. 2010. Prosedur Penelitian Suatu Pendekatan Praktik. Jakarta: PT Rineka Cipta.

Chen, Hsiang-I. 2015. "Learner Autonomy and the Use of Language Learning Strategies in a Taiwanese Junior High School. Taiwan: Ming Chuan University". Journal of Studies in Education, 5 (1) : 52-64.

Saefullah, dkk. 2013. "Hubungan Antara Sikap Kemandirian Belajar Dan Prestasi Belajar Siswa Kelas X Pada

Pembelajaran Fisika Berbasis Portofolio". Jurnal Wahana Pendidikan Fisika, 2(1):26-36.

Fitriana, Sitti dkk. 2015. "Pengaruh Efikasi Diri, Aktivitas, Kemandirian Belajar, dan Kemampuan Berpikir Logis Terhadap Hasil Belajar Matematika Pada Siswa Kelas VIII SMP". Journal of EST, 1 (2) : 86-101.

Hamdani. 2011. Strategi Belajar Mengajar.

Bandung: CV Pustaka Setia.

Mckendry, Stephanie and Vic Boyd. 2012. "Defining the "Independent Learner" in UK Higher Education: Staff and Students' Understanding of the Concept. Skotlandia: Glasgow Caledonian University. International Journal of Teaching and Learning in Higher Education", 24 (2): 209-220.

Olfin, Pembeu. 2014. "Hubungan Keaktifan di Kelas dengan Hasil Belajar Siswa pada Kelas V Di SDN 25 Palu". Elementary School of Education EJournal, 2 (3).

Oluoch, Everlyn. 2014. "Methods of Increasing Speaking Activities in the Classroom (Maximising Student Input and Involvement)". Journal of Education and Practice, 5(7): 73-81.

Ramlah, dkk. 2014. "Pengaruh Gaya Belajar Dan Keaktifan Siswa Terhadap Prestasi Belajar Matematika ( Survey Pada SMP Negeri Di Kecamatan Klari 
Kabupaten Karawang)". Jurnal Ilmiah Solusi, 1(3): 68-75.

Sugiyono. 2014. Statistika untuk Penelitian. Bandung: Alfabeta

Sundayana, Rostina. 2016. "Kaitan antara Gaya Belajar, Kemandirian Belajar, dan Kemampuan Pemecahan Masalah

Siswa SMP dalam Pelajaran Matematika". Jurnal Mosharafa, 5 (2) : 75-84.

Rijal, Syamsu. 2015. "Hubungan antara Sikap, Kemandirian Belajar, dan Gaya Belajar dengan Hasil Belajar Kognitif Siswa". Jurnal BIOEDUKATIK, 3 (2) :15-20.

Winarno. 2014. Pembelajaran Pendidikan Kewarganegaraan, Isi, Strategi, dan Penilaian. Jakarta: Bumi Aksara.

Yustianingrum, Dyahayu. 2015. "Hubungan Keaktifan dan Kemandirian Siswa Terhadap Prestasi Belajar Matematika Siswa SMP Kelas VII". Jurnal Pendidikan Matematika, 13(1) :6-9 
Yuris Setyawati /Joyful Learning Journal 6 (4) 2017 